\title{
THE POLISH CURRENT OF CRITICISM OF COMMUNISM (BOLSHEVISM) IN THE YEARS 1917-1939. BIBLIOGRAPHY OF SOURCES
}

World War I has weakened Russia involved in it. As a result of social protests at the turn of February and March 1917, the Social Democratic Provisional Government was formed. Tsar Nikolai II abdicated and Russia became a republic. The weak government of Aleksander Kerensky and chaos allowed a group of Bolsheviks, headed by Vladimir Lenin, to return from exile (on a sealed train ${ }^{2}$ ) to enact a coup on 7 November 1917 (called the October Revolution) and seize power. The new government of the Council of People's Commissioners began with a brutal, physical liquidation of opponents, executions affected masses of random people. A civil war broke out, in which the forces of the white and red army clashed. The unprecedented terror against civilians was reinforced by propaganda actions and isolation from the world. The laws and decrees promulgated by the Bolsheviks seemingly only guaranteed the working class, endowed with the role of proletariat, freedom of speech, press and assembly. In fact a new social hierarchy was created in which the privileged group was the communists, then the non-party workers and the poor. Other social groups were considered class enemies and destined for brutal re-education or extermination (clergy, landowners, aristocracy). Bloody terror and the unimaginable number of victims of the new experiment would continue to exist before the eyes of the world until Stalin's death in 1953, with the highly ambivalent behaviour of the West.

1 Prof. dr hab. Janina Kostkiewicz, head of the Department of High School Pedagogy and the Polish Pedagogical Thought in Institute of Pedagogy at the Faculty of Philosophy of the Jagiellonian University; editor-in-chief of this journal: Institute of Pedagogy UJ, ul. Batorego 12, 31-135 Kraków; e-mail: janina.kostkiewicz@uj.edu.pl.

2 Romuald Moskała SJ, “Nasz sąsiad wschodni (Szkic o bolszewizmie)”, Przegląd Powszechny 145-146 (1920), 376-388; 147-148 (1920), 33-47. 
The Polish criticism of Bolshevism from the interwar period ${ }^{3}$ is consistent with the analyses of political scientists and philosophers almost a century later. In the most general terms, the criticism of Bolshevism at the time spoke of the loss of European cultural unity-including philosophical, social and political - and a threat to the Latin civilisation. Bolshevism identified with communism was considered to be an idea that has its own history in evolution and its philosophy is Marxism. The actions of the Bolsheviks were unequivocally interpreted as an intention to create communism on a global scale ${ }^{4}$. [...].

It was stressed that a comprehensive critique of Bolshevism (communism) cannot be closed, as it lacks a final vision of culture. Even if dialectical materialism were to be taken as a "mechanism of history" and an indication of cultural change, it lacks a vision of desired culture (or it is infantile) - there is no description of paradise to be achieved. The West, meanwhile, practiced Marxism... theoretically, and practiced it in the East ${ }^{5}$.

Polish humanists of the interwar period considered the good knowledge of Bolshevism a point of honour and an expression of their identity. Thus, all sources have been explored - from the texts of Marx, Engels, Lenin, through philosophical-political analyses of other theoreticians and practitioners ${ }^{6}$, to the personal experiences of eyewitnesses. In Poland, the most comprehensive approaches to the apocalyptic phenomenon of Bolshevism have been created and a new discipline of research - Sovietology - has been initiated. The knowledge of Bolshevism was brought to perfection and considered to be the best in the world.

3 Although criticism of Bolshevism focused on its version implemented in Russia, the global expansion of Bolshevism through the activities of the Communist International was realised. Its element was a slanderous campaign against Poland - the alleged fascist governments of the Second Republic of Poland were being spread in the form of imaginary information - and the idea of communism was being spread around the world. And so, among other things, in the USA there was the Manifesto of the communist party existing there.

4 Ignacy Czuma, "Bolszewicka dialektyka moralności”, Prąd 18 (1930), 294-308; Edward Kosibowicz, "Ideowe źródła współczesnego bezbożnictwa", Przegląd Powszechny 215 (1937), 111-125; Józef Pastuszka, "Prądy materialistyczne w filozofii współczesnej”, Ateneum Kapłańskie 32 (1933), 13-38; Jan Urban, "Ideologia bolszewizmu”, Przegląd Powszechny 194 (1932), 129-143; Antoni Szymański, "Bolszewizm jako prąd kulturalny i cywilizacyjny”, Prąd 32 (1937), 207-242; Stefan Wyszyński, "Społeczeństwo i prasa a wychowanie młodzieży”, Ateneum Kapłańskie 32 (1933), 175-188.

5 This is a quote from: Janina Kostkiewicz, "Child and Family as Proletarians of the Educational Ideology of Bolshevik Marxism in the Critical Reflection of Polish Humanists from 1917-1939", Polska Myśl Pedagogiczna 6 (2020); eadem, "Polski nurt krytyki totalitaryzmów", 167-176. In: Pedagogika. Podręcznik akademicki, eds. Zbigniew Kwieciński, Bogusław Śliwerski (Warszawa: PWN, 2019).

6 In the interwar period, more than 50 magazines published in Soviet Russia had the right to distribute in Poland, including: Isvestya, Pravda, Vechernyaya Moskva, Kino-Gazeta, Literaturnaya-Gazeta, Sovetskoye Iskusstvo and Istorik-Marxist. 


\section{Bibliography: The Polish Current of Criticism of Communism (Bolshevism) in the Years 1917-1939}

1. “Dążenia komunistyczne w Polsce (Z 'Biuletynu Informacyjnego POK')”. Prąd 34 (1937), 39-59.

2. “J. Em. X. Kard. Hlond o Niemczech, Polsce i Europie”. Prąd 22 (1932), 284-288.

3. "Legion Młodych i wpływy bolszewickie". Prą 28 (1935), 49-52.

4. Metoda czy wypadek”. Prą 23 (1932), 97.

5. “Podjazdowe walki z religią w szkole”. Prąd 23-24 (1933), 267-272.

6. "Propaganda komunizmu wśród młodego pokolenia”. Miesięcznik Katechetyczny i Wychowawczy 9 (1927), 385-397.

7. “Z życia w Z.S.R.R”. Prąd 30 (1936), 38-45.

8. Adamski, Stanisław, bpp. Podstawy pracy Stowarzyszeń Akcji Katolickiej. Poznań: Naczelny Instytut Akcji Katolickiej, 1937.

9. Bauer, Otto. Bolszewizm a socyalna demokracya. Lwów: Ludowe Spółdzielcze Towarzystwo Wydawnicze, 1920.

10. Biskupski, Stefan. "W obronie katolickiego małżeństwa". Ateneum Kapłańskie 23 (1929), 63-65.

11. Bogdan 7 . Prawda o komunizmie. Kraków 1920.

12. Bolszewizm, joint publication. Lublin: Towarzystwo Wiedzy Chrześcijańskiej - Drukarnia Narodowa, 1938.

13. Bolszewizm a sprawa polska. Warszawa: Sztab Generalny, Pt. 865/VI - Druk. W. Krawczyński $\mathrm{i}$ in., 1919.

14. Bolszewizm i socjalizm. Warszawa: Wydawnictwo "Ligii Pracy", 1922.

15. Borkowska, Alina. "Nędza i ucisk dzieci pod rządem bolszewickim”. Prąd 17 (1929), 245-253.

16. Bruckus, Borys. "Kolektywizacja rolnictwa włościańskiego w Rosji Sowieckiej”. Przegląd Powszechny 199 (1933), 36-56.

17. Brzozowski, Stanisław. Kultura i życie. Zagadnienia sztuki i twórczości w walce o światopoglad. Lwów: Nakładem Drukarni Polskiej B. Połonieckiego, 1907.

18. Bystroń, Jan Stanisław. Komunizm. Lwów: Książnica - Atlas, 1939.

19. Całka, Leon. "Książka o kolektywizmie”. Prąd 26 (1934), 39-52.

20. Chmaj, Ludwik. "Pius XI, wychowawca ludzkości”. Przegląd Powszechny 222 (1939), 3-19.

21. Chojnacki, Piotr, pr. "Materializm dziejowy jako filozofia naukowego komunizmu”. Ruch Katolicki 12 (1937), 543-553.

22. Ciemniewski, Jan, pr. "Nauka szkolna w zastosowaniu do psychiki i kultury polskiej”. Polonia Sacra 3 (1919).

23. Czapiński, Kazimierz. Bankructwo bolszewizmu. Warszawa: Nakładem Księgarni Robotniczej, 1921.

24. Czuj, Jan, pr. “Z podróży na Wschód”. Prąd 22 (1932).

25. Czuma, Ignacy. "Bezskuteczność socjalizmu i bolszewizmu”. In: Postawa katolicka wobec kryzysu. Lublin: Związek Polskiej Inteligencji Katolickiej, 1933, 98-111.

26. Czuma, Ignacy. “Bezskuteczność socjalizmu i bolszewizmu”. Prąd 23 (1932), 214-227.

27. Czuma, Ignacy. “Bolszewicka dialektyka moralności”. Prąd 18 (1930), 294-308.

7 No surname, no name or only the author's initials means that the publication has been signed in this way and it is impossible to identify the author's full details. 
28. Czuma, Ignacy. Filozoficzne punkty styczne zachodu i bolszewizmu. Lublin: Koła Badań Naukowych nad Kościołami Wschodniemi XX wieku Teologów KUL - Drukarnia Narodowa, 1930.

29. Czuma, Ignacy. "Państwo sowieckie”. In: Absolutyzm ustrojowy. Wybór pism, ed. Maciej Marszał. Kraków: Ośrodek Myśli Politycznej - „Księgarnia Akademicka”, 2003, 360-378.

30. Czuma, Ignacy. "Państwo sowieckie”. Prąd 35 (1938), 63-88.

31. Czuma, Ignacy. "Prymitywizm gospodarczy rewolucji sowieckiej”. Prąd 17 (1929), 3-25.

32. EFPE. “Dookoła nawrócenia Rosji”. Przegląd Powszechny 158 (1923), 5-11.

33. E.G. "Katolicyzm a faszyzm”. Ateneum Kapłańskie 33 (1934), 174-177.

34. Gałęzowska, Irena. "Filozoficzne źródła kolektywizmu". Przegląd Powszechny 175 (1927), 45-72.

35. Gałęzowska, Irena. "Mit o jednostce zbiorowej”. Przegląd Powszechny 168 (1925), 283-291.

36. Glass, Henryk. “Istota współczesnego bolszewizmu”. Myśl Narodowa 10 (1933), 118-119.

37. Glass, Henryk. Ofensywa Komunizmu i drogi przeciwdziałania. Katowice: Księgarnia i Drukarnia Katolicka, 1938.

38. Glass, Henryk. "Przygotowanie rewolucji proletariackiej”. Myśl Narodowa 25 (1933), 357-359.

39. Glass, Henryk. Wpływ Kominternu wśród nauczycieli. Materiały oświetlające cele i taktykę komunistów w Związk Nauczycielstwa Polskiego, ed. 2. Warszawa: Centralne Biuro Porozumienia Antykomunistycznego, 1938.

40. Górski, Karol. "Personalizm a kolektywizm”. Kultura i Wychowanie 4 (1937).

41. Górski, Karol. “Sprawiedliwość i miłość w życiu społecznem”. Prąd 17 (1929), 187-196.

42. Hessen, Sergiusz. "Pedagogowie komunistyczni współczesnej Rosji”. Chowanna (Instytut Pedagogiczny w Katowicach) (1934), 49-61, 97-112.

43. Hessen, Sergiusz, Hans, Mikołaj. Pedagogika i szkolnictwo w Rosji sowieckiej. Rozwój szkolnictwa sowieckiego i zmiany komunistycznej polityki oświatowej od rewolucji październikowej do końca planu pięciolecia (1917-1932), transl. dr Adam Zieleńczyk. Lwów-Warszawa: Książnica - Atlas, 1938.

44. Hortyński, Feliks. "Proletaryzacja nauki w Rosji”. Przegląd Powszechny 151-152 (1921), 336-343.

45. J.K. "Współczesne prądy w wychowaniu”. Kwartalnik Pedagogiczny 1-2 (1938), 35-48.

46. J.N. “Komunizm i nacjonalizm w Rosji Sowieckiej”. Myśl Narodowa 20 (1933), 283-284.

47. J.W. “Z wędrówki po Rosji Proletariackiej”. Myśl Narodowa 29 (1933), 424-425.

48. Jasiński, Walery, pr. Światłocienie wspótczesnej pedagogiki. Poznań: Naczelny Instytut Akcji Katolickiej - Biblioteczka Akcji Katolickiej nr 43, 1937.

49. Jastrzębska, Jadwiga. “O równowagę kultury moralnej i materialnej”. Kwartalnik Pedagogiczny 1 (1937), 75-79.

50. Jehlićka, Franciszek. "Etyka niezależna i jej propaganda w Polsce". Przegląd Powszechny 166 (1925), 11-26, 155-165.

51. Jotgen (Jan Gołębiowski). Państwo robotników i chłopów. Toruń: Inrót, 1938.

52. Kamieński, S. "Katolicy wobec akcji Kominternu na Kresach wschodnich”. Ateneum Kapłańskie, 487-491.

53. Karasiewicz, Władysław, pr. "Komunizm, a młodzież nasza”. Miesięcznik Katechetyczny i Wychowawczy 1 (1932).

54. Kliszewicz, Adolf. “Totalizm współczesny i jego podłoże”. Ateneum Kapłańskie 44 (1939), $13-30$.

55. Koneczny, Feliks. "Państwo a metody życia zbiorowego”. Myśl Narodowa 39 (1930), 605-607.

56. Koneczny, Feliks. "Polska między Wschodem a Zachodem”. In: VI Tydzień Społeczny Stowarzyszenia Młodzieży Akademickiej “Odrodzenie”. Lublin: Uniwersytet Lubelski, 1928, 63-100. 
57. Koneczny, Feliks. “Rozmnożenie bolszewizmu”. Myśl Narodowa 32 (1930), 496-498.

58. Koniński, Karol Ludwik. "Kilka truizmów w sprawie żydowskiej”. Gazeta Literacka 10 (1933).

59. Kordacz, Franciszek, J.E.X. abpp. "Liberalizm, kapitalizm i socjalizm w świetle nauki katolickiej”. Prąd 18-2018 (1931), 322-329.

60. Korybut-Woroniecki, Henryk J. “Bezbożnictwo sowieckie”. Przegląd Powszechny 217 (1938), 186-198.

61. Korybut-Woroniecki, Henryk J. "Dwudziestolecie Rosji Sowieckiej”. Przegląd Powszechny 216 (1937), 37-52.

62. Korybut-Woroniecki, Henryk J. "Rezultaty dwudziestu lat panowania komunizmu w Rosji". Przegląd Powszechny 216 (1937), 196-204.

63. Korybut-Woroniecki, Henryk J. "Zasady komunizmu a rzeczywistość". Przegląd Powszechny 216 (1937), 328-344.

64. Kosibowicz, Edward, pr. “Ideowe źródła współczesnego bezbożnictwa”. Przegląd Powszechny 215 (1937), 111-125.

65. Kosibowicz, Edward, pr. "Wspólny front przeciw komunistyczny". Przegląd Powszechny 212 (1936), 3-13.

66. Kossak-Szczucka, Zofia. Pożoga: wspomnienia z Wołynia 1917-1919, ed. 2. Kraków: Krakowska Spółka Wydawnicza, 1923.

67. Kossak-Szczucka, Zofia. The Blaze. Reminiscences of Volhynia 1917-1919. London: Allen and Unwin, 1927.

68. Kościelecki, Władysław. "Pius XI wobec prądów religijnych w III Rzeszy”. Ateneum Kapłańskie 40 (1937).

69. Krzesiński, doc. pr. Kultura nowoczesna i jej tragizm, Kraków 1933.

70. Krzyżanowski, Adam. Bolszewizm. Kraków: Nakładem Księgarni S.A. Krzyżanowskiego, 1920.

71. Ks. S.W. “Pius XI o walce z komunizmem”. Ateneum Kapłańskie 39 (1937), 466-472.

72. Kucharzewski, Jan. Od białego caratu do czerwonego, t. I - 1923, t. 2 - 1925, t. III - 1928, t. IV - 1931, t. V - 1931, t. VI - 1933. Warszawa: Wydawnictwo Kasy im. J. Mianowskiego.

73. Kuchta, Jan. Nowe kierunki i dążenia we współczesnej katolickiej pedagogice. Lwów: Księgarnia R. Schweitzera, 1939.

74. Kwiatkowski, Antoni (pseud. Antoni Starodworski). Dzieje cerkwi prawosławnej w Z.S.R.R. (czy ze zniszczeniem cerkwi zniszczona została potrzeba religji w narodzie). Warszawa: Instytut Naukowego Badania Komunizmu, 1934.

75. Kwiatkowski, Antoni (pseud. Antoni Starodworski). Istota i cechy bolszewizmu współczesnego $w$ Rosji sowieckiej. Studium socjologiczne na podstawie źródet i spostrzeżeń własnych. Sowiecka reforma rolna, vol. 1. Warszawa: Gebethner i Wolf, 1927.

76. Kwiatkowski, Antoni (pseud. Antoni Starodworski). Istota i cechy bolszewizmu wspótczesnego $w$ Rosji sowieckiej. Istota i cechy komunistycznej polityki ekonomicznej na tle paragrafu 13-go programu rosyjskiej Partii Komunistycznej, vol. 2. Warszawa: Gebethner i Wolf, 1927.

77. Kwiatkowski, Antoni. Katolicyzm a komunizm. Warszawa, 1936.

78. Kwiatkowski, Antoni (pseud. Antoni Starodworski). Losy obywateli - rolników w Bolszewji. Warszawa: Druk. "Lech", 1927.

79. Kwiatkowski, Antoni (pseud. Antoni Starodworski). Małżeństwo 'cywilne' w Bolszewizmie i jego skutki. Warszawa: Druk. "Lech", 1927.

80. Kwiatkowski, Antoni (pseud. Antoni Starodworski). Sowiety nad Cisq. Warszawa: "Kolumna", 1936.

81. Kwiatkowski, Antoni (pseud. Antoni Starodworski). Zamach bolszewicki na samorzad polski. Warszawa: Wydawnictwo Ligii Antybolszewickiej, 1931. 
82. Kwiatkowski, Franciszek, pr. "Komunizm a religia". In: Raj komunistyczny. Przemowy na wiecu przeciwkomunistycznym. Kraków: Wydawnictwo Apostolstwa Modlitwy, seria "Komunizm bez maski" no. 1, 1937.

83. Kwiatkowski, Franciszek, pr. Oświata i życie rodzinne w Sowietach. Warszawa: Nakładem "Głosu Pracy Polskiej” - Druk. "Lech", 1927.

84. Kwiatkowski, Franciszek, pr. Teozofia i antropozofia czyli nauka tajemna o Bogu i człowieku. Poznań: Nakładem Ligi Katolickiej, 1925.

85. Kwiatkowski, Franciszek, pr. Źródło dzisiejszego bezbożnictwa. Kraków: Wydawnictwo Apostolstwa Modlitwy, seria "Komunizm bez maski" no. 2, 1937.

86. Lutosławski, Wincenty. Bolszewizm i Polska. Wilno: Wydawnictwo Komitetu im. Braci Józefa i Marjana Lutosławskich, 1920.

87. Ławicz, Z., pseud. (Adam Powojski). Polacy w piekle bolszewickiem. Warszawa: Drukarnia W. Rybicki i s-ka, 1920.

88. M. "Sergiusz Hessen i Mikołaj Hans, Pedagogika i szkolnictwo w Rosji sowieckiej (19171932). Przełożył Adam Zieleńczyk. Biblioteka Przekładów Dzieł Pedagogicznych pod redakcją dr. Zygmunta Ziembińskiego. Nr. 24. Lwów-Warszawa, Książnica - Atlas, Str. 308”. Kwartalnik Pedagogiczny 1 (1935), 56-59.

89. Manteuffel, Marian. "Głębsze przyczyny tzw. 'kryzysu światowego' (Odczyt wygłoszony dn. 23 kwietnia 1932 roku w Stowarzyszeniu Młodzieży Akademickiej 'Odrodzenie’ w Warszawie)". Prąd 23 (1932), 3-20.

90. Martini, W. “Prawda o pracy przymusowej w Rosji Sowieckiej”. Myśl Narodowa 27 (1933), 397.

91. Michalski, Konstanty, pr. “Dzień ognia”. In: Konstanty Michalski. Nieznanemu Bogu. Kraków: Koło Studiów Katolickich i Naukowy Instytut Katolicki, 1936.

92. Michalski, Konstanty, pr. "Fermenty religijne w Trzeciej Rzeszy”. Przeglad Powszechny 201 (1934), 347-367.

93. Michalski, Konstanty, pr. Gasnące blaski. Kraków. Biblioteczka „Czasu” no. 8, 1934.

94. Michalski, Konstanty, pr. "Nieznanemu Bogu”. In: Konstanty Michalski. Nieznanemu Bogu. Kraków. Koło Studiów Katolickich i Naukowy Instytut Katolicki, 1936.

95. Michalski, Konstanty, pr. Nieznanemu Bogu. Kraków: Koło Studiów Katolickich i Naukowy Instytut Katolicki, 1936.

96. Michalski, Konstanty, pr. "Resurectio et Vita". In: Konstanty Michalski. Nieznanemu Bogu. Kraków: Koło Studiów Katolickich i Naukowy Instytut Katolicki, 1936.

97. Michalski, Konstanty, pr. “Tomizm wobec współczesnej filozofii dziejów”. In: Księga Pamiątkowa Międzynarodowego Kongresu Filozofii Tomistycznej w Poznaniu 1934 rok. Gniezno: „Studia Gnesnensia”, vol. XII, 1935, 1-29.

98. Michalski, Konstanty, pr. “Trzy mity”. In: Konstanty Michalski. Nieznanemu Bogu. Kraków: Koło Studiów Katolickich i Naukowy Instytut Katolicki, 1936, 18-39.

99. Michalski, Konstanty. “Zagadnienia współczesnej filozofii dziejów”. Przegląd Współczesny 115 (1931).

100. Miecewicz, Stanisław. “Plan pięciolecia w Związku Sowietów”. Przegląd Powszechny 193 (1932), 296-318.

101. Mikes, Jan, hr. bpp. "Komunizm i nacjonalizm w świetle chrześcijańskiego światopoglądu”. Ruch Katolicki V (1935), 100-110.

102. Moskała, Romuald SJ. "Nasz sąsiad wschodni (Szkic o bolszewizmie)". Przegląd Powszechny 145-146 (1920), 376-388; 147-148 (1920), 33-47.

103. Mysłakowski, Zygmunt. Totalizm czy kultura. Kraków: Spółdzielnia Wydawnicza "Czytelnik", 1938. 
104. Niemancewicz, Adam. Bolszewizm a wychowanie. Warszawa: Gebethner i Wolff, 1929.

105. Niesiołowski, Andrzej. “Czy totalizm jest koniecznością historyczną?”. Przegląd Powszechny 215 (1937), 82-95.

106. Niesiołowski, Andrzej. "Hiszpańskie medytacje”. Przegląd Katolicki 35 (1936), 599-601.

107. Niesiołowski, Andrzej. "Ideologizacja kultury”. Kultura i Wychowanie 1 (1937).

108. Niesiołowski, Andrzej. Katolicyzm a totalizm. Poznań: NIAK, 1938.

109. Niesiołowski, Andrzej. Nowoczesny kryzys rodziny i jego przyczyny. Poznań: NIAK, 23.

110. Niesiołowski, Andrzej. O ideologjach polityczno-społecznych. Poznań: Drukarnia św. Wojciecha, 1935.

111. Niesiołowski, Andrzej. "Personalizm a kolektywizm”. Kultura i Wychowanie 1 (1937), 16-34.

112. Niesiołowski, Andrzej. “Perspektywy totalizmu”. Przegląd Powszechny 215 (1937), 204-214.

113. Niesiołowski, Andrzej. “Zagadnienie 'pacyfizmu’ słowiańskiego”. Przegląd Powszechny 210 (1936).

114. Niesiołowski, Andrzej. “Zmierzch materializmu”. Przegląd Powszechny, kwiecień, 1938.

115. Około-Kułak, Antoni, pr. "Bolszewicki kodeks karny”. Przegląd Powszechny 157 (1923), 117-124.

116. Około-Kułak, Antoni, pr. "Bolszewizm a religia". Przegląd Powszechny 155-156 (1922), 193-202.

117. Olechnowicz, Franciszek. Prawda o Sowietach. Wrażenia $z$ 7-letniego pobytu w więzieniach sowieckich r. 1927-1933. Warszawa: Nakł. Autora, 1937.

118. PP. “Akcja komunizmu wśród młodzieży francuskiej”. Przegląd Powszechny 169 (1926), 338 352, 376-378.

119. Parandowski, Jan. Bolszewicy i bolszewizm w Rosji. Lwów: H. Altenberg - Drukarnia L. Dankiewicza (Stanisławów), 1920.

120. Pastuszka, Józef, pr. Filozofja współczesna, t. 1. Warszawa: Gebethner i Wolff, 1934.

121. Pastuszka, Józef, pr. "Prądy materialistyczne w filozofii współczesnej”. Ateneum Kapłańskie 32 (1933), 13-38.

122. Pawlak, Bernard. Czerwone niebezpieczeństwo. Prawda o komunizmie. Poznań: NIAK, 1937.

123. Pepłowska, B. "Międzynarodowy kongres antybolszewicki”. Prąd 19 (1930), 264-268.

124. Piskorz, Juljan. "Materjalizm praktyczny człowieka dzisiejszego". Ateneum Kapłańskie 31 (1933), 216-243.

125. Piwowarczyk, Jan, pr. Socjalizm i chrześcijaństwo. Kraków: Drukarnia Głos Narodu, 1934.

126. Piwowarczyk, Jan, pr. “Z fermentów w socjalizmie”. Prąd 1 (1926), 79.

127. Podoleński, Stanisław, pr. "Akcja komunizm wśród młodzieży francuskiej”. Przegląd Powszechny 169 (1926), 375-330.

128. Podoleński, Stanisław, pr. “Dziecko proletariatu”. Przeglad Powszechny 170 (1926), 338-352.

129. Podoleński, Stanisław, pr. "Etyka katolicka a eugenika i medycyna". Przeglad Powszechny 214 (1937), 195-208.

130. Podoleński, Stanisław, pr. “Herman Muckermann: Gestaltung der Lebenslage. XVI Aufl.” Przegląd Powszechny 203 (1934).

131. Podoleński, Stanisław, pr. “Jak socjalizm wychowuje lud?". Przegląd Powszechny 149-150 (1921), 93-109.

132. Podoleński, Stanisław, pr. “O poszanowanie kobiety”. Przegląd Powszechny 181 (1929), 333-348.

133. Podoleński, Stanisław, pr. "Papież dla głodnych dzieci”. Przegląd Powszechny 151-152 (1921), 90-93.

134. Podoleński, Stanisław, pr. “Projekt polskiej ustawy eugenicznej”. Przegląd Powszechny 204 (1934), 387-393. 
135. Podoleński, Stanisław, pr. Rodzina w Sowietach. Kraków: Wydawnictwo Apostolstwa Modlitwy - Księża Jezuici, seria "Komunizm bez maski” no. 3.

136. Podoleński, Stanisław, pr. “Socjalizm a rodzina”. Ruch Katolicki 5 (1935), 467-475.

137. Podoleński, Stanisław, pr. "Socjalizm w trosce o kobietę". Przegląd Powszechny 179 (1928), 233-251.

138. Podoleński, Stanisław, pr. "Szkolnictwo i wychowanie w Rosji bolszewickiej”. Przegląd Powszechny 165 (1925), 121-128.

139. Podoleński, Stanisław, pr. "U kolebki marksizmu”. Przegląd Powszechny 182 (1929), 113-117.

140. Podoleński, Stanisław, pr. "W sprawie polskiej YMCA”. Przegląd Powszechny 162 (1924), 97-116.

141. Podoleński, Stanisław, pr. "Walka z komunizmem”. Przeglą Powszechny 178 (1928), 394-396.

142. Podoleński, Stanisław, pr. "Wychowawczo-oświatowa akcja socjalizmu w Polsce”. Przegląd Powszechny 177 (1928), 257-272; 178 (1928), 282-305.

143. Prawda o Komunizmie. Biuletyn Informacyjny, ed. Henryk Glass. [Subsequent issues discussed: the activities of the Communist Internationale, communism of Soviet Russia, anti-Bolshevik actions, a review of world of anti-communist literature]. Warszawa.

144. Raj komunistyczny. Przemowy na wiecu przeciwkomunistycznym. Kraków: Wydawnictwo Apostolstwa Modlitwy, 1937.

145. Rostworowski, Jan, pr. "Jan Kucharzewski: Od białego do czerwonego caratu, t. I, wydawnictwo Kasy im. Mianowskiego, Warszawa 1923, str. 432”. Przegląd Powszechny 160 (1923), 259-261.

146. Rostworowski, Jan, pr. "Świat pod grozą postępów bolszewizmu. - Tragedia Hiszpanii. Na froncie religijnym polskim”. Przegląd Powszechny 210 (1936).

147. Roszkowski, Antoni. Katolicyzm społeczny. Zarys rozwoju poglądów społeczno-katolickich. Poznań: Księgarnia św. Wojciecha, 1932.

148. Roszkowski, Antoni. "Rola Kościoła w rozwiązaniu kwestii społecznej w oświetlaniu encykliki 'Rerum Novarum”. Ateneum Kapłańskie 28 (1931), 429-447.

149. Roszkowski, Antoni. “Światowa organizacja robotników Chrześcijańskich M. K. Ch. Z. Z.”. Ateneum Kapłańskie 23 (1929), 86-94.

150. Skaliński, J. “O należytą postawę wobec komunizmu”. Przegląd Powszechny 215 (1937), 96-110.

151. Skaliński, J. “Socjaliści a komuniści”. Przegląd Powszechny 217 (1938), 361-374.

152. Skaliński, J. “Wobec nowej taktyki komunizmu”. Przegląd Powszechny 213 (1937), 137-153.

153. Sołoniewicz, Iwan. Rosja w obozie koncentracyjnym, vol. 1-2, transl. Stanisław Dębicki. Lwów: Sekretariat Porozumiewawczy Polskich Organizacji Społecznych, 1938.

154. Srokowski, Konstanty, Elita bolszewicka. Studjum socjologiczne. Kraków: Krakowska Spółka Wydawnicza, 1927.

155. St. PP. "U kolebki Marksyzmu”. Przegląd Powszechny 182 (1929), 113-117.

156. Stein, Ignacy. "Rodzina jako społeczność wychowująca, jej prawa i obowiązki”. Ruch Katolicki 1 (1931), 318-322.

157. Stepa, Jan, pr. Komunizm a światopogląd katolicki. Poznań: Nakładem Komitetu Międzynarodowego Kongresu Chrystusa-Króla, 1937.

158. Stepa, Jan, pr. Kościół a współczesny kryzys wolności. Lwów: Instytut Wyższej Kultury Religijnej, 1939.

159. Stepa, Jan, pr. “Wpływ nauki Kościoła na kształtowanie się myśli społecznej”. In: Katolicka myśl społeczna. Pamiętnik III Studium Katolickiego w Warszawie 5-10. IX.37. Poznań: NIAK, 1938.

160. Stopniak, Piotr. “Cerkiew rosyjska wobec bolszewizmu”. In: Bolszewizm. Lublin: Towarzystwo Wiedzy Chrześcijańskiej, 1938. 
161. Stopniak, Piotr. “Cerkiew rosyjska wobec bolszewizmu”. Prą 35 (1938), 3-32.

162. Studnicki, Władysław. Wobec nadchodzacej drugiej wojny światowej. Warszawa: Nakładem Autora, 1939.

163. Suchodolska, Felicja. "Propaganda ateistyczna komunizmu". Ruch Katolicki (1933), 433-438.

164. Suchodolska, Felicja. "Propaganda komunistyczna za pomocą teatru robotniczego". Ruch Katolicki (1933), 281-283.

165. Symonolewicz, Konstanty. "Literatura piękna w Rosji Sowieckiej”. Przegląd Powszechny 197 (1933), 164-178.

166. Szymański, Antoni, pr. "Bezskuteczność statolatryzmu i nacjonalizmu”. Prąd 23 (1932), 203-210.

167. Szymański, Antoni, pr. Bolszewizm. Poznań: Księgarnia św. Wojciecha, 1929.

168. Szymański, Antoni, pr. "Bolszewizm jako prąd kulturalny i cywilizacyjny”. Prąd 32 (1937), 207-242.

169. Szymański, Antoni, pr. “Etatyzm a wolność gospodarcza”. Prąd 17 (1929), 247-258.

170. Szymański, Antoni, pr. Polityka społeczna. Lublin: Nakładem Uniwersytetu Lubelskiego, 1925.

171. Szymański, Antoni, pr. Spisek niemiecko-bolszewicki. Dokumenty, dotyczace związku bolszewików z niemieckim naczelnym dowództwem, wielkim przemysłem i finansami oraz reprodukcja fotograficzna dokumentów. Warszawa: Committee of Public Information, 1919.

172. Szymański, Antoni, pr. "Wpływy rewolucji bolszewickiej”. Prąd 11-12 (1926), 421-444.

173. Szymański, Antoni, pr. "Wskazania socjalne”. Prąd 18 (1930), 363-376.

174. Szymański, Antoni, pr. Wyzwolenie proletariatu. Poznań: NIAK, 1937.

175. Szymański, Antoni. Zagadnienie społeczne, ed. 3. Lublin: Towarzystwo Wiedzy Chrześcijańskiej - Uniwersytet, 1939.

176. Środki walki z bolszewizmem. Bydgoszcz, Wydawnictwo “Antikom”, 1920.

177. Tochowicz, Paweł, pr. "Filozofia i pedagogika socjologizmu”. Ateneum Kapłańskie 35 (1935), 441-454; 36 (1935), 28-45.

178. Tochowicz, Paweł, pr. "Pedagogika radykalno-społeczna”. Ateneum Kapłańskie 36 (1935), 238$255 ; 37$ (1936), 258-270.

179. Trojanowski, S. "Komunizm a wolność". In: Raj komunistyczny. Przemowy na wiecu przeciwkomunistycznym. Kraków: Wydawnictwo Apostolstwa Modlitwy, 1937.

180. Turowski, Konstanty. "Komunizm a dobrobyt". In: Raj komunistyczny. Przemowy na wiecu przeciwkomunistycznym. Kraków: Wydawnictwo Apostolstwa Modlitwy, 1937.

181. Turowski, Konstanty. "Nowa strategia polskiego socjalizmu”. Prąd 37 (1939), 315-332.

182. Urban, Jan, pr. "Bolszewicy wobec religii w Rosji, na Węgrzech i w Bawarii. Stosunek państwa do Kościoła w przyszłej konstytucji niemieckiej”. Przegląd Powszechny 141-142 (1919), 389-395.

183. Urban, Jan, pr. "Bolszewizm w zagadnieniu o początkach chrześcijaństwa”. Przegląd Powszechny 141-142 (1919), 1-19.

184. Urban, Jan, pr. “Czy można socjalizm pogodzić z katolicyzmem?”. Przegląd Powszechny 169 (1926), 3-20, 164-182.

185. Urban, Jan, pr. "Ideologia bolszewizmu”. Przegląd Powszechny 194 (1932), 129-143.

186. Urban, Jan, pr. "Katolicyzm a kultura”. Przeglad Powszechny 205 (1935), 46-68.

187. Urban, Jan, pr. "Konstanty Srokowski, Elita bolszewicka. Studjum socjologiczne”. Przegląd Powszechny 175 (1927), 174-176.

188. Urban, Jan, pr. "Nasz stosunek do socjalizmu". Przegląd Powszechny 174 (1927), 145-161, 314-340.

189. Urban, Jan, pr. "Pius XI a Rosja dysydencka”. Przeglą Powszechny 183 (1929), 257-266. 
190. Urban, Jan, pr. "Przenikanie bezbożnictwa do umysłowości polskiej”. Przegląd Powszechny 210 (1936), 12-28.

191. Urban, Jan, pr. “Prześladowanie religji w Rosji”. Przegląd Powszechny 185 (1930), 129-141.

192. Urban, Jan, pr. "Socjalizm jako religia”. Przegląd Powszechny 151-152 (1921), 5-23.

193. Urban, Jan, pr. "W obliczu wojującego ateizmu”. Przegląd Powszechny 188 (1930), 257-273.

194. W.J. “Z wędrówki po Rosji proletariackiej”. Myśl Narodowa 29 (1933).

195. Walczyński, Franciszek. "Mit XX wieku”. Przegląd Powszechny 219 (1938), 202-211.

196. Wasilewski, Jan. Książka o głodzie. Kraków: Wydawnictwo Księży Jezuitów, 1922.

197. Wasilewski, Jan. "Prawosławie wobec Bolszewizmu”. Przegląd Powszechny 160 (1923), 213-221.

198. Wasilewski, Jan. W szponach antychrysta: wspomnienia księdza z Rosji bolszewickiej. Kraków: Wydawnictwo Księży Jezuitów, 1924.

199. Weryński, Henryk, pr. "Bezdroża wychowania”. Ruch Katolicki 6 (1936), 414-423.

200. Weryński, Henryk, pr. "Kościół katolicki wobec przemian fizjonomii Europy”. Ruch Katolicki 4 (1934), 9-14.

201. Weryński, Henryk, pr. "Laicyzm w swym rozwoju historycznym”. Ruch Katolicki 1 (1931), 369-375.

202. Wóycicki, Aleksander, pr. Socjalizm a religia. Studium socjologiczne. Poznań-Warszawa: Księgarnia św. Wojciecha, 1920.

203. Wyszyński, Stefan, pr. "Akcja katolików polskich dla ofiar kryzysu gospodarczego". Ateneum Kapłańskie 28 (1931), 370-378.

204. Wyszyński, Stefan, pr. "Antyreligijne wychowanie w organizacjach socjalistycznych". Ateneum Kapłańskie 42 (1938), 485-490.

205. Wyszyński, Stefan, pr. “Arma Veritatis - Watykańska Wystawa Prasy Katolickiej”. Ateneum Kapłańskie (1936), 307-320.

206. Wyszyński, Stefan, pr. "Głos Episkopatu 'o ducha chrześcijańskiego w Polsce’ a opinja publiczna”. Ateneum Kapłańskie 33 (1934), 385-395.

207. Wyszyński, Stefan, pr. "Głos od grobu św. Wojciecha o zasadach życia państwowego”. Ateneum Kapłańskie 30 (1932), 176-182.

208. Wyszyński, Stefan, pr. “Główne typy Akcji Katolickiej za granicą”. Prąd 20 (1931), 85-91, $113-$ $133,185-200$.

209. Wyszyński, Stefan, pr. Katolicyzm, kapitalizm, socjalizm. List pasterski biskupów austriackich. Lublin: Towarzystwo Wiedzy Chrześcijańskiej - Uniwersytet, 1933.

210. Wyszyński, Stefan, pr. "Konferencja w sprawie duszpasterstwa wśród robotników”. Ateneum Kapłańskie 37 (1939), 127-136.

211. Wyszyński, Stefan, pr. "Kościół i miłosierdzie wobec klęski bezrobocia". Ateneum Kapłańskie 28 (1931), 130-150.

212. Wyszyński, Stefan, pr. Kultura bolszewicka a inteligencja polska. Włocławek: Księgarnia Powszechna, 1934.

213. Wyszyński, Stefan, pr. "Kultura bolszewizmu a inteligencja polska". Ateneum Kapłańskie 33 (1934), 35-48, 139-157.

214. Wyszyński, Stefan, pr. "Myśl katolicka wobec nieładu w gospodarstwie międzynarodowym". Ateneum Kapłańskie 30 (1932), 503-506.

215. Wyszyński, Stefan, pr. "Nowe metody walki religijnej w Rosji Sowieckiej”. Ateneum Kapłańskie 31 (1933), 159-165.

216. Wyszyński, Stefan, pr. "Nowy najazd komunizmu na Polskę". Ateneum Kapłańskie (1936), 69-78. 
217. Wyszyński, Stefan, pr. "Pokłosie encykliki 'Quadragesimo Anno’. (Głosy Episkopatu Austrii i Węgier)”. Ateneum Kapłańskie 29 (1932), 480-483.

218. Wyszyński, Stefan. "Prace katolickich tygodni społecznych”. Ateneum Kapłańskie 32 (1933), 422-427.

219. Wyszyński, Stefan, pr. "Przewodnie myśli encykliki o chrześcijańskim wychowaniu młodzieży”. Ateneum Kapłańskie 26 (1930), 1-22.

220. Wyszyński, Stefan, pr. "Ruch katolicko-społeczny”. Ateneum Kapłańskie 36 (1935), 396-407; 37 (1936), 65-73.

221. Wyszyński, Stefan, pr. "S. Hessen i M. Hans, Pedagogika i szkolnictwo w Rosji Sowieckiej”. Ateneum Kapłańskie 35 (1935), 523-524.

222. Wyszyński, Stefan, pr. “Socjalistyczna własność wspólna w ocenie ‘Rerum Novarum”. Ateneum Kapłańskie 28 (1931), 470-486.

223. Wyszyński, Stefan, pr. "Społeczeństwo i prasa a wychowanie młodzieży". Ateneum Kapłańskie 32 (1933), 175-188.

224. Wyszyński, Stefan, pr. “Świat katolicki w 40-stą rocznicę encykliki 'Rerum Novarum”'. Ateneum Kapłańskie 28 (1931), 505-523.

225. Wyszyński, Stefan, pr. "Z ostatnich walk o religijny charakter szkoły polskiej”. Ateneum Kapłańskie 30 (1932), 53-61.

226. Wyszyński, Stefan, pr. "Z ostatnich walk o religijny charakter szkoły polskiej”. In: Katolicka myśl społeczna. Pamiętnik III Studium Katolickiego w Warszawie 5-10.IX.37. Poznań: NIAK, 1938.

227. Wyszyński, Stefan, pr. “Zasięg i charakter zainteresowań katolickiej myśli społecznej”. In: Katolicka myśl społeczna. Pamiętnik III Katolickiego Studium w Warszawie 5-10.IX.37. Poznań: NIAK, 1938.

228. Z.M. "Ernst Krieck. Wychowanie narodowo-polityczne, przeł. O. Wawrzkowicz. Wstęp napisał dr Antoni Ryniewicz. - Bibl. Prz. Dz. Ped. T. 32 pod red. Dr Zygmunta Ziembińskiego. Książnica - Atlas, Lwów-Warszawa, str. 269”. Kwartalnik Pedagogiczny 1-2 (1937), 61-63.

229. Zahorska, Anna. "Oblicze bolszewizmu (na marginesie literatury polskiej o rewolucji bolszewickiej)”. Przegląd Powszechny 168 (1925), 319-328.

230. Zajdlicz, Aleksander, pseud. (Andrzej Niesiołowski). “Pojednani bracia w Marksie”. Przeglad Katolicki 18 (1937).

231. Zdziechowski, Marjan. Europa, Rosja, Azja. Szkice polityczno-literackie. Warszawa: Drukarnia "Znicz", 1922.

232. Zdziechowski, Marjan. Od Petersburga do Leningradu. Wilno: Drukarnia J. Bajewski, 1934.

233. Zdziechowski, Marjan. Terror intelektualny w Rosji. Warszawa: Drukarnia Kasy im. Mianowskiego, 1937.

234. Zdziechowski, Marjan. "Widmo przyszłości: Rosja, bolszewizm, Polska”. Głos (1988).

235. Źródła dzisiejszego bezbożnictwa, praca zbiorowa. Kraków: Księża Jezuici, seria "Komunizm bez maski" no. 2 .

236. Żychliński, Aleksander, pr. Metafizyka komunizmu a mądrość Chrystusowa. Poznań: Druk. Fr. Krajna, 1937. 